\title{
Exploration of Instrumental and Integrative Motivation for Reading English as a Second Language among Second Year Pre-University Students of Government MAO College, Lahore (Pakistan)
}

\author{
Tahir Jahan Khan', Azlina Murad Sani², Sarimah Shaikh-Abdullah² \\ ${ }^{1}$ School of Arts and Sciences, Universiti Utara Malaysia, Sintok, Kedah, Malaysia \\ ${ }^{2}$ School of Education and Modern Languages, Universiti Utara Malaysia, Sintok, Kedah, Malaysia \\ Email:tjniazi9@gmail.com
}

Received 28 February 2016; accepted 18 April 2016; published 21 April 2016

Copyright (C) 2016 by authors and Scientific Research Publishing Inc.

This work is licensed under the Creative Commons Attribution International License (CC BY).

http://creativecommons.org/licenses/by/4.0/

(c) (i) Open Access

\begin{abstract}
Since the 1970s work of Gardner and Lambert, studies on language learning motivation have received much consideration in second language research. More recently, studies on reading motivation have also gained much interest. This study was conducted among $\mathbf{4 0}$ male second year pre-university students of Government MAO College, Lahore (Pakistan) to investigate the levels of instrumental and integrative motivation for reading English as a Second Language (ESL). Data were collected through an adapted version of Dornyei's language learning motivation questionnaire, and analyzed by means of descriptive statistics. The findings indicate that the students were more strongly instrumentally motivated for reading English in their context. It was also found that the students have relatively lower levels of integrative motivation for reading English. Based on the findings and implications, recommendations are made for the enhancement of motivation for reading English in the Pakistani context.
\end{abstract}

Keywords

Instrumental and Integrative Motivation, ESL, Pre-University, Reading English

\section{Introduction}

Reading motivation can be described as "an individual's goals and beliefs” for reading ([1], p. 199). There are

How to cite this paper: Khan, T.J., Sani, A.M. and Shaikh-Abdullah, S. (2016) Exploration of Instrumental and Integrative Motivation for Reading English as a Second Language among Second Year Pre-University Students of Government MAO College, Lahore (Pakistan). Open Journal of Social Sciences, 4, 69-76. http://dx.doi.org/10.4236/jss.2016.44010 
many studies which have been conducted among children to investigate the reading motivation and reading development, especially in the mother tongue [2]-[7]. The majority of these studies have focused on intrinsic and extrinsic motivation and related constructs in accordance with the taxonomy of [8].

At the same time, a considerable number of studies have been conducted on language learning motivation since the initial work of [9], many of which are based on the Socio-educational Model [10]-[13]. The impact of Gardner and his colleagues has been felt in numerous studies of second language learning motivation, including [14]-[20], which have mainly explored instrumental and integrative motivations for learning a language.

In the Pakistani context, various studies have been conducted to investigate learning motivation [21]-[23]. These studies have concentrated the focus on various educational settings where English is learned as a second language. However, few have explored reading motivation.

English is a compulsory subject at the pre-university level of Pakistan. The ability to read in English has a vital role in learning because the students have to accomplish their assignments on the basis of English reading. Reading in English becomes compulsory as various written activities in their final examinations are based on reading English. This shows that much is at stake for Pakistani students with regard to reading in English. However, this issue has not been addressed extensively in empirical studies. Therefore, the current study is an initial exploration of the role of instrumental and integrative motivation for reading English as a Second Language (ESL) among Pakistan pre-university students.

\section{Context of the Study}

Government MAO (Muhammadan Anglo Oriental) College, Lahore is one of the major public sector colleges of the province of Punjab (Pakistan). It has been declared autonomous with other 26 public sector colleges of Punjab to run BS Honor Classes in various disciplines in 2009. However, pre-university or intermediate first year and second year classes still continue alongside Master and BS Honor classes in various disciplines in this college.

The term "pre-university" refers to Intermediate first and second year levels in public sector colleges of Pakistan. Therefore, these terms are being used in this study to denote the same academic level. The students of this pre-university level are reading in ESL. English is a compulsory subject and also a medium of instruction. The students have to read four (4) prescribed reading text books apart from English Grammar. Passing or failing English determines the pre university result. The students have to participate in one full English reading period of 45 minutes daily in a week. English is also an official language of the country but this issue is controversial [24]-[29].

\section{Objectives of the Study}

This study was conducted to determine the levels of Instrumental and Integrative motivation for reading ESL among pre-university students of MAO College, Lahore (Pakistan). It has the following objectives.

1) To determine the overall level of motivation for reading ESL.

2) To examine the levels of Instrumental and Integrative Motivation for reading ESL.

\section{Research Questions}

The study, which was conducted in November of the 2015-2016 academic year ventured to obtain answers to the following research questions:

1) What is the level of motivation for reading ESL among the second year students?

2) What are the students' levels of Instrumental and Integrative Motivation for reading ESL?

\section{Significance of the Study}

It was expected that the students would read English for both instrumental and integrative motivations. By focusing on male-only participants, the detailed results regarding both types of motivation would be able to provide a practical profile that may assist teachers for improvement in the reading levels, and therefore possibly assist towards a better path for success.

\section{Review of Literature}

\subsection{Motivation}

Motivation is one of the major factors which influence learning [16]. According to [16], motivation is a pulling 
force which "provides the primary impetus to initiate learning the L2 and later the driving force to sustain the long and often tedious learning process” (p. 117). While researchers and scholars differ regarding the definitions of term, they seem to agree "that motivation is responsible for determining human behaviour by energising it and giving it direction” [16] (p. 117). According to [29] and [30], motivation is a power which sustains the efforts for a goal-oriented objective. Motivation has been defined by [31] (p. 28) as a "process involved in the direction, vigor, and persistence of behavior". This suggests that the process of motivation is greatly affected by many related forces and constructs. Effort, desire and effect are three essential parts of motivation [11]. Thus motivation is a psychological term which is considered, in language learning processes, to be the desire, necessity, or wish to learn or acquire something [32].

\subsubsection{Types of Motivation}

1) Intrinsic and Extrinsic Motivation

According to [8], reading motivation studies, particularly in the first language context, have mainly focused on intrinsic and extrinsic motivation, for reading development and comprehension. According to [3] (p. 2), in reading motivation, the term intrinsic is "to read for its own sake" while [2] have regarded extrinsic motivation as reading for getting external values and rewards such as to avoid the punishment of teachers or to gain appreciation from parents. Therefore, extrinsic motivation is connected with performance goal orientation. This suggests doing well for getting others' approval [3]. Empirical studies conducted in reading motivation in L1 and L2, the model of Guthrie and his colleagues has been popular [2] [3] [33]-[36]. Many studies used the Motivation for Reading Questionnaire (MRQ) and have mostly researched younger school going students reading L1. [35]'s MREQ (Motivation for Reading in English Questionnaire) has been adapted from the Motivation for Reading Questionnaire (MRQ) to examine the L2 reading motivation among EAP (English for Academic Purposes) students. Studies in L2 academic reading motivation that have applied the constructs of extrinsic and extrinsic motivation include [35] and [36].

2) Instrumental and Integrative Motivation

While many L1 studies have focused on extrinsic and intrinsic motivation, instrumental and integrative motivations are two social-psychological based notions of motivation present in L2 learning motivation studies [9]-[12] [37]. These have also been used in Pakistani-context studies for investigations of ESL learning motivation [21]-[23] [27] [28] [38]. The term instrumental motivation suggests that people are motivated to do or achieve something through utilization of a language to get worldly benefit, such as financial gains [25] [27] [28] [38]. Instrumental motivation has been shown to affect the learning process for employment or professional accomplishment in the studies conducted in Pakistani context. Recent conceptualizations suggest two forms of instrumental motivation-promotion (e.g. motivation for self-advancement) and prevention (e.g. motivation not to fail or disappoint) [39]. However, this study focuses only on the former element.

Integrative motivation, on the other hand, generally suggests the attempt by the language learner to associate or relate with the culture or traditions of the people of the target language. In this case, one may learn another language, for instance, to develop a form of intimacy with its speakers, and/or with motives to learn more about the culture or integrate with the target community [10]. Studies of this nature include [32] and [40]. While this notion is considered less relevant with English becoming an international language, it may still play a role in specific sociocultural contexts [39], and might apply in Pakistan.

In addition to the L2 Motivational Self System [39], Dornyei's Process Model of L2 Motivation also relate elements of integrative and instrumental motivation to language learning. For example, in the latter, goal oriented values or instrumental motivation and language related attitudes or integrative motivation are expected to have a role in goal oriented behavior [41] [42].

L2 reading motivation studies using L2-based motivational concepts is less documented. Therefore, this study has chosen to explore ESL reading motivation, focusing on the notions of instrumental and integrative motivation rather than intrinsic and extrinsic motivation.

\section{Methodology}

\subsection{Participants}

The participants of the study were forty (40) male students of Government MAO College, Lahore (Pakistan). These students were enrolled in English Reading Class for the second year of pre-university level of the aca- 
demic session of 2015-2016.

\subsubsection{Instrument}

The data for this study were collected through a questionnaire survey. The instrument was based on Dornyei's L2 learning motivation questionnaire [43], which was modified to elicit data for reading ESL, and also to suit the Pakistani setting.

17 questionnaire items from the Instrumental and Integrative Motivation items of [43] were adapted by rewriting each item to include the word "reading English" as substitute for the original words "studying English". Participants responded to all the items on a 5-point Likert Scale.

The questionnaire comprised three parts: The first part elicited participants' general demographic data. The second part consisted of ten items relating to instrumental motivation (promotion) for reading English. While the third part had 7 items related to integrative motivation for reading English, and included selected items from integrativeness, cultural interest and attitude towards L2 community of [43]. One new item on reading literature was added.

\subsubsection{Data Analysis}

Responses were run on SPSS (Statistical Package for Social Sciences) program; percentages and mean scores on the 5-point scale were generated. Scores were interpreted using the following criteria as in the following table.

\begin{tabular}{cc}
\hline Mean Range & Interpretation \\
\hline $3.69-5.00$ & High Level of Motivation \\
$2.35-3.68$ & Moderate Level of Motivation \\
$1.00-2.34$ & Low Level of Motivation \\
\hline
\end{tabular}

\section{Findings}

The findings of this study are reported below, according to the sections of the questionnaire.

\subsection{General Description of the Participants}

The 40 (100\%) participants were all male (100\%) and their age distribution is shown in Table 1.

Most of the participants were aged between 18 and 19 years. 20 year olds were in the minority. This is the usual age range for students of this college.

\subsection{Instrumental Motivation for Reading}

Table 2 shows the responses on instrumental motivation for reading ESL. Participants of this study tended to have high level of instrumental motivation for reading English, with an overall mean of 4.36, and individual item mean scores ranging from 4.21 to 4.57 on the 5-point scale. The main instrumental motivation to read in English was to achieve a special goal, e.g., to get a degree or scholarship (Item 9), while good employment appeared to be the strongest instrumental motivation (Item 1, 2, and 4). Students were least motivated to read for further studies in their major subject (Item 6, mean 4.21).

\subsection{Integrative Motivation for Reading}

Table 3 shows that the overall degree of integrative motivation for reading English among the respondents was also in the high range, with an average score of 3.93. The highest mean rating was given to item 3 (I like English reading very much) which lacked any specific motivation source. However, other items seem to suggest a motivation to read to gain more knowledge about literature, arts and culture (Items $4,1,10$ ). They were only moderately motivated to read popular material in English, or to know more about English speaking people. They are comparatively more motivated by the idea of becoming part of the English reading community [Item 2], but are less drawn to popular English language sources (Item 7).

Table 4 provides us the comparison between instrumental and integrative motivation for reading English, as well as the overall means. The mean score for both types of motivation of 4.14 is reflected as a high level of motivation. 
Table 1. Age of the participants.

\begin{tabular}{ccc}
\hline Age (Years) & Frequency & Percentage (\%) \\
18 & 15 & 37.5 \\
19 & 17 & 42.5 \\
20 & 08 & 20 \\
Total & 40 & 100 \\
\hline
\end{tabular}

Table 2. Mean scores for instrumental motivation for reading.

\begin{tabular}{|c|c|c|c|c|}
\hline & Items & Mean & SD & Motivation Level \\
\hline 1) & $\begin{array}{l}\text { Reading English can be important to me because I think it will be } \\
\text { useful in getting a good job. }\end{array}$ & 4.41 & 0.47 & High \\
\hline 2) & $\begin{array}{l}\text { Reading English is important to me because } \\
\text { English proficiency is necessary for promotion in the future. }\end{array}$ & 4.46 & 0.52 & High \\
\hline 3) & $\begin{array}{l}\text { Reading English is important to me because with English I can work } \\
\text { globally. }\end{array}$ & 4.31 & 0.46 & High \\
\hline 4) & $\begin{array}{l}\text { Reading English can be important to me because I think it will } \\
\text { someday be useful in getting a good job and/or making money. }\end{array}$ & 4.46 & 0.55 & High \\
\hline 5) & $\begin{array}{l}\text { Reading English is important because with a high level of English } \\
\text { proficiency I will be able to make a lot of money. }\end{array}$ & 4.35 & 0.71 & High \\
\hline 6) & $\begin{array}{l}\text { Reading English can be important for me because I think I'll need it } \\
\text { for further studies on my major. }\end{array}$ & 4.21 & 0.52 & High \\
\hline 7) & $\begin{array}{l}\text { Reading English can be important to me because I think I'll need it } \\
\text { for further studies. }\end{array}$ & 4.26 & 0.54 & High \\
\hline 8) & $\begin{array}{l}\text { I read English in order to keep updated and informed of recent news } \\
\text { of the world. }\end{array}$ & 4.31 & 0.54 & High \\
\hline 9) & $\begin{array}{l}\text { Reading English is important to me in order to achieve a special goal } \\
\text { (e.g., to get a degree or scholarship). }\end{array}$ & 4.51 & 0.48 & High \\
\hline 10) & The things I want to do in the future require me to use English. & 4.33 & 0.60 & High \\
\hline & Total mean & 4.36 & 0.55 & High \\
\hline
\end{tabular}

\section{Table 3. Mean scores for integrative motivation for reading.}

\begin{tabular}{|c|c|c|c|c|}
\hline & Items & Mean & SD & Motivation Level \\
\hline 1) & $\begin{array}{l}\text { I read English is in order to learn more about the culture and art of its } \\
\text { speakers. }\end{array}$ & 3.46 & 0.79 & Moderate \\
\hline 2) & $\begin{array}{l}\text { I read English to become similar to the people } \\
\text { who read English. }\end{array}$ & 3.68 & 0.81 & High \\
\hline 3) & I like reading in English very much. & 4.41 & 0.73 & High \\
\hline 4) & I like reading English literature of the native speaker. & 4.40 & 0.67 & High \\
\hline 5) & I like to read English magazines, newspapers and books. & 3.61 & 0.85 & Moderate \\
\hline 6) & I read English because I want to travel in English-speaking countries. & 4.33 & 0.79 & High \\
\hline \multirow[t]{2}{*}{ 7) } & I read English to know more about English-speaking people. & 3.61 & 1.04 & Moderate \\
\hline & Total mean & 3.93 & 0.81 & High \\
\hline
\end{tabular}

Table 4. Overall motivation for reading English.

\begin{tabular}{cccc}
\hline Motivation Type & Mean & SD & Motivation Level \\
\hline Instrumental Motivation for Reading & 4.36 & 0.55 & High \\
Integrative Motivation for Reading & 3.93 & 0.81 & High \\
Total & 4.14 & 0.68 & High \\
\hline
\end{tabular}




\section{Discussion and Conclusions}

The result of the study shows that the second year pre-university students of Government MAO College, Lahore (Pakistan) are both instrumentally and synthetically motivated towards reading English as a second language. The study suggests that Pakistani students read ESL for utilitarian goals that are related to self-advancement, either immediate in nature, or for the longer term. Although integrative motivation is also high, especially with regards to the esteem for English literature and interest in reading for its own sake and for future travel, instrumental motivation is slightly stronger than integrative motivation. The fact that instrumental motivation is high is consistent with past studies on extrinsic motivation to read in English among tertiary students of ESL/EFL outside the native speaker context [35] [36]. The students' strong liking for reading English suggests a positive relationship between reading motivation and reading amount, such as [34].

Within the Pakistani context of English learning, the findings of this study provide further evidence to support the idea that there is a high level of instrumental motivation for English learning, and particularly among tertiary students [21] [22] [28] [29] [44]. The instrumental motivation observed also strengthens the impression that students understand that English performs a dynamic role in their lives in the present time and also in their future [44]-[46]. This study also supports instrumental and integrative motivation with the role of extrinsic and intrinsic motivation in the study conducted by [47] among the university learners in Japan and Sri Lanka.

On the basis of high levels of motivation for reading English, it is hoped that the findings will be able to provide the local institution with better insights into male students' motivations for reading in English. The following recommendations are proposed:

1) The students' strong inclination towards reading English could very well be related to the value of reading in their institution. Although reading motivation levels are currently very satisfactory, the institution could increase the utility value of reading in the English syllabi by paying attention to the choice of reading materials.

2) Integrative motivation for reading is relatively lower than instrumental motivation. Integrative motivation could be promoted, if necessary, by incorporating activities related to the students' interest such as educational visits to English speaking countries.

This small-scale study however, only sought to explore and profile instrumental and integrative aspects of reading motivation among males in this particular setting. Further studies could attempt to establish the reliability and validity of this instrument for use in reading specific motivation, as well as conduct studies that are generalizable to a larger population, and a variety of academic contexts.

\section{References}

[1] Guthrie, J.T. and Wigfield, A. (1999) How Motivation Fits into a Science of Reading. Scientific Studies of Reading, 3, 119-205. http://dx.doi.org/10.1207/s1532799xssr0303_1

[2] Wang, J.H. and Guthrie, J.T. (2004) Modeling the Effects of Intrinsic Motivation, Extrinsic Motivation, Amount of Reading, and Past Reading Achievement on Text Comprehension. Reading Research Quarterly, 39, 162-186. http://dx.doi.org/10.1598/RRQ.39.2.2

[3] Baker, L. and Wigfield, A. (1999) Dimensions of Children's Motivation for Reading and Their Relations to Reading Activity and Reading Achievement. Reading Research Quarterly, 34, 452-477. http://dx.doi.org/10.1598/RRQ.34.4.4

[4] Watkins, M. and Coffey, D.Y. (2004) Reading Motivation: Multidimensional and Indeterminate. Journal of Educational Psychology, 96, 162-186. http://dx.doi.org/10.1037/0022-0663.96.1.110

[5] Guthrie, J.T. (2000) Engagement and Motivation in Reading. In: Kamil, M.L., Mosenthal, P.B., Pearson, P.D. and Barr, R., Eds., Handbook of Reading Research: Volume III, Erlbaum, New York.

[6] Guthrie, J.T., Mcrae, A. and Klauda, S.L. (2007) Contributions of Concept-Oriented Reading Instruction to Knowledge about Interventions for Motivations in Reading. Educational Psychologist, 42, 237-250. http://dx.doi.org/10.1080/00461520701621087

[7] Guthrie, J.T., Hoa, A.L.W., Wigfield, A., Tonks, S.M., Humenick, N.M. and Littles, E. (2007) Reading Motivation and Reading Comprehension Growth in the Later Elementary Years. Contemporary Educational Psychology, 32, $282-313$. http://dx.doi.org/10.1016/j.cedpsych.2006.05.004

[8] Wigfield, A. and Guthrie, J.T. (1997) Relations of Children’s Motivation for Reading to the Amount and Breadth or Their Reading. Journal of Educational Psychology, 89, 420-432. http://dx.doi.org/10.1037/0022-0663.89.3.420

[9] Gardner, R.C. and Lambert, W.E. (1972) Attitudes and Motivation in Second Language Learning. Newbury House, Rowley. 
[10] Gardner, R.C. and Lambert, W.E. (1959) Motivational Variables in Second Language Acquisition. Canadian Journal of Psychology, 13, 266-272. http://dx.doi.org/10.1037/h0083787

[11] Gardner, R.C. (1985) Social Psychology and Second Language Learning: The Role of Attitudes and Motivation. Edward Arnold, London.

[12] Gardner R.C. and Maclntyre, P.D. (1993) A Student's Contributions to Second Language Learning. Part II: Affective variables. Language Teaching, 26, 1-11. http://dx.doi.org/10.1017/S0261444800000045

[13] Tremblay, P.F. and Gardner, R.C. (1995) Expanding the Motivation Construct in Language Learning. Modern Language Journal, 79, 505-520.

[14] Pintrich, P.R. and de Groot, E.V. (1990) Motivational and Self-Regulated Learning Components of Classroom Academic Performance. Journal of Educational Psychology, 82, 33-40. http://dx.doi.org/10.1037/0022-0663.82.1.33

[15] Csize, K. (2005) Language Learners’ Motivational Profiles and Their Motivated Learning Behavior. Language Learning, 55, 613-659.

[16] Dörnyei, Z. (1998) Motivation in Second and Foreign Language Learning. Language Teaching, 31, 117-135. http://dx.doi.org/10.1017/S026144480001315X

[17] Honkomp, B. (2011) Adventure Learning: Motivating Students in a Minnesota Middle School. Journal of Research on Technology in Education, 43, 231-252.

[18] Huang, S. and Tung, N.C. (2008) Assessing Motivation and Learning Strategies Using the Motivated Strategies for Learning Questionnaire in a Foreign Language Learning Context. Social Behavior and Personality, 36, 529-534.

[19] Gardner, R.C. and Lysynchuk, L.M. (1990) The Role of Aptitude, Attitudes, Motivation, and Language Use on Second-Language Acquisition and Retention. Canadian Journal of Behavioural Science, 22, 254-270. http://dx.doi.org/10.1037/h0078924

[20] Khodadady, E. and Ashrafborji, M. (2013) Motivations Underlying English Language Learning and Achievement. SAGE Open, 3, 1-8. http://dx.doi.org/10.1177/2158244013484157

[21] Ahmed, M. (2015) Students’ Motivation toward English Language Learning at Undergraduate Level. Advances in Language and Literary Studies, 6, 230-238.

[22] Noreen, S., Ahmed, M. and Esmail, A. (2015) Role of Students' Motivation, Attitude and Anxiety in Learning English at Intermediate Level in Pakistan: A Gender Based Study. Educational Research International, 4, 96-108.

[23] Yaqoob, M., Ahmed, M. and Arshad, M. (2014) Motivation and ESL Learning Self-System in Pakistani Students. Research on Humanities and Social Sciences, 4, 150-160.

[24] Rahman, T. (1999) Language, Education, and Culture. Oxford University Press, Karachi.

[25] Rahman, T. (2006) Language Policy, Multilingualism and Language Vitality in Pakistan. Trends in Linguistics Studies and Monographs, 175, 73.

[26] Rahman, T. (1997) The Urdu—English Controversy in Pakistan. Modern Asian Studies, 31, 177-207. http://dx.doi.org/10.1017/S0026749X00016978

[27] Mansoor, S. (2003) Language Planning in Higher Education Issues of Access and Equity. The Lahore Journal of Economics, 8, 17-42.

[28] Mansoor, S. (2004) The Status and Role of Regional Languages in Higher Education in Pakistan. Journal of Multilingual and Multicultural Development, 25, 333-353. http://dx.doi.org/10.1080/01434630408666536

[29] Pintrich, P.R. and Shunk, D.H. (1996) Motivation in Education: Theory, Research and Applications. Prentice Hall, Englewood Cliffs.

[30] Murphy, P.K. and Alexander, P.A. (2000) A Motivated Exploration of Motivation Terminology. Contemporary Educational Psychology, 25, 3-53. http://dx.doi.org/10.1006/ceps.1999.1019

[31] Guthrie, J.T., Wigfield, A. and VonSecker, C. (2000) Effects of Integrated Instruction on Motivation and Strategy Use in Reading. Journal of Educational Psychology, 92, 331-341. http://dx.doi.org/10.1037/0022-0663.92.2.331

[32] Noris-Holt, J. (2001) Motivation as a Contributing Factor in Second Language Acquisition. The Internet TESL Journal, VII.

[33] Wigfield, A. and Eccles, J. (2000) Expectancy-Value Theory of Achievement Motivation. Contemporary Educational Psychology, 25, 68-81. http://dx.doi.org/10.1006/ceps.1999.1015

[34] Lin, D., Wong, K.K. and McBride-Chang, C. (2012) Reading Motivation and Reading Comprehension in Chinese and English among Bilingual Students. Reading and Writing, 25, 717-737. http://dx.doi.org/10.1007/s11145-011-9297-8

[35] Komiyama, R. (2013) Factors Underlying Second Language Reading Motivation of Adult EAP Students. Reading in a Foreign Language, 25, 149-169. 
[36] Sani, A.M., Tengku Ariffin, T.F. and Shaik-Abdullah, S. (2014) I'll Read in English if...: A Glimpse into the Nature of Tertiary ESL Reading Motivation. Procedia-Social and Behavioral Sciences, 118, 343-350. http://dx.doi.org/10.1016/j.sbspro.2014.02.047

[37] Tremblay, P.F. and Gardner, R.C. (1995) Expanding the Motivation Construct in Language Learning. Modern Language Journal, 79, 505-518.

[38] Shamim, F. (2011) English as the Language for Development in Pakistan: Issues, Challenges and Possible Solutions. Dreams and Realities: Developing Countries and the English Language, 291-310.

[39] Dornyei, Z. and Ushioda, E. (2011) Teaching and Researching Motivation. 2nd Edition, Pearson, Harlow.

[40] Guthrie, J.T., Hoa, A.L.W., Wigfield, A., Tonks, S.M., Humenick, N.M. and Littles, E. (2007) Reading Motivation and Reading Comprehension Growth in the Later Elementary Years. Contemporary Educational Psychology, 32, 282-313. http://dx.doi.org/10.1016/j.cedpsych.2006.05.004

[41] Dörnyei, Z. and Otto, I. (1998) Motivation in Action: A Process Model of L2 Motivation. Working Papers in Applied Linguistics, 4, 43-69.

[42] Dörnyei, Z. (1990) Conceptualizing Motivation in Foreign-Language Learning. Language Learning, 40, 45-78. http://dx.doi.org/10.1111/j.1467-1770.1990.tb00954.x

[43] Dornyei, Z. (2010) Questionnaires in Second Language Research: Construction, Administration, and Processing. 2nd Edition, Routledge, London. http://www.zoltandornyei.co.uk/

[44] Khan, T.J. and Khan, N. (2016) Obstacles in Learning English as a Second Language among Intermediate Students of Districts Mianwali and Bhakkar, Pakistan. Open Journal of Social Sciences, 4, 154-162. http://dx.doi.org/10.4236/jss.2016.42021

[45] Pathan, H. Shahriar, A. and Mari, M. (2010) Motivation for Learning English in Pakistan. EFL Annual Research Journal, 12, 75-91.

[46] Waseem, F. and Jibeen, T. (2013) Anxiety amongst Learners of English as a Second Language: An Examination of Motivational Patterns in the Pakistani Context. International Journal of Humanities and Social Science, 3, 174-184. http://www.ijhssnet.com/journals/Vol 3 No 16 Special Issue August 2013/20.pdf

[47] Dhanapala, K.V. (2006) Intrinsic Motivation, Extrinsic Motivation and L2 Reading Comprehension of University Learners in Japan and Sri Lanka. Proceedings of the JACET Summer Seminar, Japan, 6, 39-43. 